\title{
ESCRIBIR «CARTAS ATERRADORAS» EN EL PALACIO DO LIMOEIRO (PORTUGAL, 1822-1825)*
}

por

\author{
RITA MARQUILHAS \\ CRISTINA ALBINO \\ Universidade de Lisboa-Centro de Linguística
}

RESUMEN: En una fase de la bistoria de Portugal marcada por la crisis del Antiguo Régimen, cuando las tensiones políticas y sociales propiciaban el aumento de la criminalidad, $y$ particularmente del bandolerismo, ve la luz una nueva moda, la de escribir desde la prisión cartas con amenazas de extorsión firmadas por salteadores ficticios. Un análisis histórico-lingüístico de 85 cartas de este tipo, escritas entre 1822 y 1825, nos coloca frente a toda una comunidad de individuos en su contexto bistórico que plantea, de manera informal, una crítica de las prácticas comunicativas del momento y reinventan, de un modo muy particular, los lugares comunes de la epistolografía de su tiempo.

Palabras Clave: Escritura epistolar. Cultura escrita. Portugal. Bandolerismo. Crisis de Antiguo Régimen.

ABSTRACT: At a moment in Portuguese history characterised by the crisis of Ancien Regime, when political and social crises catalysed an increase in crime, and in particular banditry, there emerged the custom of writing from prison threatening letters with the objective of extortion, signed by anonymous delinquents. A bistorical-linguistic analysis of 85 of these letters written between 1822 and 1825 allows a glimpse of a community of individuals in their own historical context, and of their informal critique of contemporary practices of communication.

KEY WORDS: Epistolary writing. Written culture. Portugal. Banditry. Crisis of the Old Régime.

* Traductor: J. León Acosta.

SIGLAS:

IAN/TT - Instituto dos Arquivos Nacionais/Torre do Tombo (Lisboa) 


\section{INTRODUCCIÓN}

Camilo Castelo Branco, uno de los escritores más representativos del Romanticismo portugués, ironizaba retóricamente en 1862 sobre su incapacidad para arrancarle una gran novela a la vida real de un salteador famoso de su época, José do Telhado ${ }^{1}$. Decía que los bandoleros nacionales, teniendo en cuenta las dimensiones del país, sufrían una persecución desmedida. Por ello no podían inspirar personajes literarios densos, como los creados por románticos alemanes y franceses:

Si un hada mala les hubiese torcido el destino a Schiller, Victor Hugo o Charles Nodier dejándolos caer en una cuna portuguesa, tendrían que haber inventado bandoleros ilustres, ya que no encontrarían modelos dignos para tomar apuntes al natural. Apenas un salteador novato comienza a medrar dando sus primeros golpes y al instante le salen al campo el administrador con sus cabos, el alférez con su destacamento, el periodismo poniendo el grito en el cielo en defensa de la propiedad. Y allá se fue la vocación del salteador en manos de la justicia. [...] José Teixeira da Silva do Telhado, el más famoso salteador de este siglo, no tiene la figura novelesca que se merece porque en este país ni siquiera cuajan los ladrones para novelas.

El humor con que Camilo condescendía con el personaje de José do Telhado pasaba por el manejo de una antítesis entre la violencia de los bandidos y la sutileza de los rateros sofisticados: «Robar industriosamente es obra de ingenio; saquear a hierro y fuego es robo", escribía. Aunque la expresión "robar industriosamente» nos parezca hoy día arcaicamente literaria, una figura de estilo camiliana, no era esa la acepción que tenía en el siglo XIX. El «industrioso modo de robar» era a la sazón una categoría de crimen y, al hablar así, Camilo no hacía otra cosa que glosar la terminología vulgar de comisarios y jueces del crimen ${ }^{2}$. Es más, al manipular el contraste entre el ladrón industrioso y el salteador que "traía el pecho descubierto y el trabuco apuntado al enemigo", cuyo final era acabar preso y desterrado, Camilo reavivaba algo que todavía estaría en la memoria de algunos portugueses, la historia de las «cartas aterradoras», una moda que corría en los años veinte: cartas falsas escritas en nombre de salteadores en las que se amenazaba a los destinatarios con robo, incendio o muerte en caso de que se negaran a pagar una contribución para el mantenimiento y defensa en tribunal de los «camaradas» detenidos en Lisboa en el $\mathrm{Pa}$ lacio Do Limoeiro.

Con la perspectiva que da el paso del tiempo, el caso gana una dimensión histórico-antropológica. Las «cartas aterradoras» se nos aparecen como refracciones culturales de un fenómeno universal -el de los usos comunicativos del

1 Castelo Branco, Camilo: Memórias do cárcere, vol. 2 [1862\}, Lisboa, 1927, 7. a ed., pp. 75-77.

2 V. infra, $\$ 4$.

Hispania, LXV/3, núm. 221 (2005) 991-1020 
lenguaje- y permiten que percibamos cómo una comunidad de individuos, dentro de un contexto histórico específico, hace su particular crítica informal de las prácticas comunicativas del momento. En estas cartas, el manejo de tópicos epistolográficos, combinando convenciones con recreaciones de las mismas, contiene una reflexión implícita sobre la forma y función de la escritura comunicativa en aquella sociedad. La argumentación que contienen, el conjunto documental que forman y sus propias características físicas permiten ese tipo de interrogación historiográfica - teorizado sobre todo por Roger Chartiercuyo objeto es la «significación» de los textos leídos en el pasado, indisociable de lo codificado en su respectiva «forma».

Si queremos comprender la apropiación y las interpretaciones de un texto en toda su historicidad, necesitamos identificar el efecto, en lo que toca a su significado, producido por sus formas materiales ${ }^{3}$.

En el presente trabajo dejamos a un lado el valor de prueba documental de las «cartas aterradoras» de 1822-1825, al cual no le concedemos mayor profundidad que el de simple apariencia; en contrapartida, sin embargo, destacaremos el modo como aflora en ellas toda una cultura comunicativa: creación y recepción de textos, prácticas convencionales y materialidades que tienen poco de casual.

\section{El fUTURo ARquiVo Português da Escrita QUOTIDIANA}

El debate sobre la relación de los individuos y las sociedades con la materia gráfica es relativamente reciente y ha sido punto de encuentro de una amplia investigación por parte de diferentes disciplinas, sobre todo de la antropología, la historia, la psicología y la lingüística. A partir de 1963, el antropólogo Jack Goody intentó en sucesivos libros y artículos corregir la falta de atención prestada a la Escritura como fenómeno social por parte de la antropología tradicional, en general más preocupada por la interpretación de las sociedades preliterarias. Goody construyó entonces una teoría que partía de la observación de la importancia evidente de las potencialidades de la tecnología gráfica, y acababa reivindicando las múltiples consecuencias psicológicas, cognitivas y sociales desencadenadas por la introducción de la escritura en la historia de las sociedades ${ }^{4}$.

3 CHARTIER, Roger: Forms and Meanings, Filadelfia, 1995, p. 2. Esta es una perspectiva que entronca directamente con la crítica textual moderna (Chartier cita sobre todo a D.F. McKenzie) y con los esfuerzos de esa disciplina para no «des-socializar la comprensión histórica de las obras literarias»: McGANN, Jerome J.: A Critique of Modern Textual Criticism, Chicago-Londres, 1983, p. 121.

4 V., sobre todo, GooDY, Jack (ed.): Literacy in Traditional Societies, Cambridge, 1968, pero también los trabajos posteriores: Íd.: The Domestication of the Savage Mind, Cambridge, 1977 y Íd.: The Logic of Writing and the Organisation of Society, Londres-Nueva York, 1986. 
El modelo de Goody, aunque haya sido criticado posteriormente por su etnocentrismo y por su concepción equivocada de la escritura como realidad independiente del habla ${ }^{5}$, tuvo la ventaja epistemológica de convertir la cultura escrita en un objeto de investigación que dinamizó muchas disciplinas, a lo que se sumó la fortuna de que convergiesen en este mismo campo trabajos de autores tan carismáticos como los historiadores Armando Petrucci, Roger Chartier y Fernando Bouza Álvarez, la psicóloga Emilia Ferreiro; el «humanista» Jack Ong, el psicolingüista David Olson, el neurólogo Alexandre Castro Caldas o la lingüista Claire Blanche-Benveniste.. Como consecuencia, se produjo un avance importante en el conocimiento sobre la relación entre usos de la escritura y cambios culturales, adquisición de la escritura y cambios cognitivos, dominio de la escritura y funcionamiento cerebral.

No obstante, para algunos investigadores interesados por las formas de la escritura, su uso y sus consecuencias, ha existido siempre un obstáculo: el de la detección y selección de datos. A diferencia de los antropólogos, psicólogos y neurólogos, que pueden adentrarse por la senda del trabajo experimental y crear realidades observables, los historiadores de la cultura, la sociedad y la lengua tienen que explorar los archivos existentes, organizados en la mayoría de los casos según una lógica derivada de la historia de la literatura o de la historia de las instituciones. Archivos de textos que respondan al uso que le fueron dando a la escritura en su vida diaria personas procedentes de todas las clases sociales, gente en muchos casos anónima, produciendo objetos manuscritos efímeros destinados a contactar con alguien tal vez distante o a dejar un registro de reflexiones cotidianas, a anotar datos para no olvidar algo o a exponer una protesta en un lugar visible y legible, a hacer la publicidad efímera de un producto... Esos archivos son bien escasos.

En Portugal comienza ahora, precisamente, a surgir la intención de fundar un archivo de la escritura cotidiana, el Arquivo Portugues da Escrita Quotidiana, inspirado en parte en los archivos de escritura popular o de memoria popular que han ido surgiendo en los últimos tiempos sobre todo en Italia y España ${ }^{6}$. De todas formas, como ensayo dirigido hacia ese objetivo mayor, todavía distante, está ya en curso la exploración de las cartas portuguesas familiares y de prisioneros, escritas entre los siglos XVII y XIX, a partir del inventario y estudio del acerbo textual de los procesos judiciales. Dicha investigación se encuadra dentro de dos proyectos de mayor alcance del Centro de Lingüística de la Universidad de Lisboa, desde donde, entroncando con la herencia filológica de Luís Filipe Lindley Cintra, se procura localizar, interpretar y editar críticamente

s STREET, Brian y Celia Roberts: «Spoken and Written Language», en COULMAS, Florian (ed.): The Handbook of Sociolinguistics, Oxford, 1998, pp. 169-186.

6 Archivo Diaristico Nazionale de Pieve Santo Stefano, Archivo della Scrittura Popolare de Trento, Archivo Ligure della Scrittura Popolare de Génova, Arxiu de la Memòria Popular de la Roca del Vallès, Archivo de la Escritura Popular «Bajo Duero», Museo del Pueblo de Asturias y Arquivo da Emigración Galega.

Hispania, LXV/3, núm. 221 (2005) 991-1020 
textos importantes para la historia lingüística o literaria de la lengua portuguesa, ya se trate de textos inéditos o de textos con ediciones poco satisfactorias. Este artículo se integra, precisamente, dentro de esa línea de trabajo ${ }^{7}$.

\section{CONTEXTO POLÍTICO-SOCIAL DE LAS CARTAS ATERRADORAS}

Los documentos analizados para este artículo fueron escritos en plena «crisis del Estado del Antiguo Régimen", que en Portugal se inicia en 1807, coincidiendo con las invasiones franco-españolas, y termina en 1834 con el triunfo del liberalismo tras una guerra civil de dos años entre absolutistas y liberales. Durante ese período de transición, el accidentado y lento avance de las ideas político-sociales inspiradas en la Revolución Francesa se debió en gran medida al arraigo y resistencia del antiguo sistema absolutista y sus estructuras señoriales, probablemente porque, como observa Miriam Halpern Pereira, venían defendiéndose desde el siglo anterior con un modelo atenuado de liberalismo económico ${ }^{8}$.

En el plano ideológico se puede considerar que estos años, e incluso toda la mitad del siglo XIX, estuvieron atravesados también en Portugal por la lucha entre dos sistemas de referencia: el revolucionario y el contrarrevolucionario, el racionalista y el antirracionalista. En el bando revolucionario estaban los liberales, que habían llegado al poder por primera vez en 1820 e intentaban aplicar en la práctica política los principios de libertad, igualdad, ciudadanía, tolerancia y representatividad nacional difundidos por los ilustrados europeos ${ }^{9}$. En el bando opuesto, a semejanza de lo que ocurría con los legitimistas franceses y los carlistas españoles, está la causa miguelista, defendida por los conservadores y cuyo adalid era el propio infante Don Miguel. Estos asumieron un discurso dirigido a seducir a las masas populares basado en el antiliberalismo y en la defensa de la causa de Don Miguel como legítimo heredero al trono. Aunque presentase alguna variación según el nivel de radicalismo contrarrevolucionario, se trataba de un discurso de un nacionalismo primitivo, sintetizado por Maria Alexandre Lousada con esta media docena de principios:

7 Por toda a parte... Geografia e bistória da língua portuguesa, proyecto aprobado dentro del ámbito del Programa Lusitânia para 2004-2005 y financiado por el Instituto Camões; MATE, Modern and Ancient Texts' study and Edition, tarea 3, párrafo e), programa financiado plurianualmente (20032005, POCTI n. ${ }^{\circ}$ 1279) por la Fundação para a Ciência e a Tecnologia del Ministério da Ciência e do Ensino Superior portugués. Agradecemos la colaboración de Sara de França Sousa en las tareas de recogida y clasificación de datos, que han permitido el arranque de este último proyecto.

8 V. Pereira, Miriam Halpern: «A crise do Estado de Antigo Regime: alguns problemas conceptuais e de cronologia», en Ler História, 2 (1983), pp. 3-14.

9 VARGUES, Isabel Nobre: «O processo de formação do primeiro movimento liberal: a Revolução de 1820», en MATtoso, José (dir.): História de Portugal, vol. 5 [O Liberalismo (1807-1890), coord. por Luís Reis Torgal y João Lourenço Roque], Lisboa, 1993, p. 47. 
El rechazo total de la revolución, identificada con el caos, las fuerzas del mal y lo extranjero; el elogio sistemático del pasado y de la tradición; una concepción pesimista del hombre y la identificación del orden natural con la tradición, con «lo que siempre fue»; el recurso permanente a la historia y a la supervaloración de ésta por oposición a la razón; una concepción providencialista de la historia (Dios es el "motor" de la historia); una concepción organicista de la sociedad, en la cual se basa su crítica a la libertad y a la igualdad y su defensa de los privilegios ${ }^{10}$.

Desde el punto de vista político, las tensiones parecen haber sido constantes a lo largo de toda esta época, aunque haya habido fases de aparente tranquilidad, como la que medió entre el final de las guerras napoleónicas (1814) y la revolución liberal de 1820 . Durante esos años, y para aquella realidad social y política, la oposición al régimen absolutista le auguraba un colapso seguro y espontáneo, marcado por la rebelión y la anarquía ${ }^{11}$. Esto podría tratarse de simple destructivismo, pero incluso los historiadores de hoy, que desdramatizan la situación apoyándose en las estadísticas y en el cruce de las fuentes, ven el primer cuarto del siglo XIX portugués como una época política marcada por lo inevitable del cambio que se avecinaba:

Bajo esta continuidad en la superficie [de 1814 a 1820] se escondían, sin embargo, mutaciones de calado, que, acumulándose y potenciándose mutuamente, van a provocar el aumento de las tensiones sociales y políticas, conduciendo al régimen a un punto de ruptura ${ }^{12}$.

Cuando llegó el régimen liberal, cuya primera experiencia duró desde 1820 hasta 1823 , se detectaba en la vida cotidiana del país una señal alarmante de esas tensiones: el aumento de la criminalidad. El nuevo gobierno asumió el combate contra la falta de seguridad pública como una de sus prioridades, para lo cual, además, venía animado por una propuesta de organización social en la que el poder político sería ejercido con «racionalidad» y no con «brutalidad». Si la vida cotidiana del pueblo, al que se le anunciaba un horizonte de felicidad, era perturbada por crímenes diarios, el nuevo orden corría el riesgo de ser naturalmente desacreditado ${ }^{13}$.

10 LOUSADA, Maria Alexandre: «O Miguelismo, um discurso contra-revolucionário», en DA CostA, Fernando Marques, Francisco Contente Domingues y Nuno Gonçalo Monteiro (org.): Do Antigo Regime ao liberalismo, 1750-1850, Lisboa, 1989, p. 121.

11 V. DiAs, Graça y José Sebastião da Silva: Os primórdios da Maçonaria em Portugal, vol. 1, tomo 2, Lisboa,1980, pp. 653-654.

12 AleXANDRE, Valentim: Os sentidos do império. Questāo nacional e questäo colonial na crise do Antigo Regime portugues, Oporto,1999, p. 373.

13 V. SuBTIL, José Manuel Lousada Lopes: O Vintismo e a criminalidade (1820/1823), Lisboa, Universidade Nova de Lisboa, Faculdade de Ciências Sociais e Humanas (tesis doctoral), 1986, pp. 9 y 205.

Hispania, LXV/3, núm. 221 (2005) 991-1020 
Uno de los crímenes cada vez más frecuentes era el de bandolerismo ${ }^{14}$, una variante de robo que todavía no estaba tipificada con claridad en el ordenamiento penal. Este prohibía tan sólo el robo, más grave que el burto por ser practicado con violencia, o "por la fuerza»: «Ninguna persona, independientemente de su condición, tome cosa alguna por la fuerza y contra la voluntad de aquel que la tuviere en su poder». Se consideraba, por añadidura, que el crimen de robo merecía pena más grave si era cometido «en camino o en el campo o en cualquier lugar fuera de las poblaciones» ${ }^{15}$. En su trabajo sobre ese primer período liberal, $O$ Vintismo e a criminalidade, basándose en documentación de las Cortes liberales (1820-1823) y de su Comisión de Justicia Criminal, José Subtil describe en estos términos las fechorías de los salteadores, que tanto minaban la popularidad del nuevo régimen:

Bien armados y montados, atacan a veces poblaciones enteras, haciéndose con todo lo que pueden rebañar. Cuando entran en la casa de un ciudadano la dejan pelada, y lo mismo sucede cuando asaltan en los caminos. Un estilo de actuación que conduce al "facineroso" y "malhechor» a un uso más intenso de la violencia: puertas destrozadas a hachazos, incendios para cubrir la huida o, en último recurso, el asesinato. En caso de resistencia, no duda en dejar al propietario degollado, apaleado o acuchillado, preparando así —con el terror- futuras incursiones ${ }^{16}$.

Investigadores de la historia literaria y de la historia social portuguesa han hecho notar que este fenómeno del bandidaje decimonónico — que se prolonga hasta la segunda mitad del siglo ${ }^{17}$ — adquirió cierta elaboración con la consagración literaria del bandolero como personaje romántico y con la conversión del bandolero en enemigo del liberalismo, dentro del campo de la política.

En lo que atañe a la dramaturgia y a la novelística, tras una época de traducciones de literatura europea sobre salteadores, inaugurada exitosamente con la pieza de Schiller Die Räuber (1781), llegó el turno de la fabulación romántica de los salteadores nacionales, que dieron lugar a algunas narrativas de terror que inauguraron la variante portuguesa del «fuera de la ley que lucha por el triunfo de la justicia» ${ }^{18}$. La obra más significativa de esta corriente será Paulo, 0

\footnotetext{
14 «Habiéndose observado que de un tiempo a esta parte son más frecuentes los robos perpetrados con fuerza armada por bandos de salteadores [...]». Circular del Intendente General de Policía a los Corregidores del Reino, Lisboa, 3 de febrero de 1821, ed. por SuBtil, José Manuel Lousada Lopes: $O$ Vintismo..., ob. cit., p. 34.

is Ordenaçöes filipinas, lib. 5, tít. 61 [1603-1870], Lisboa, 1985, p. 1210; v. también SuBTIL, José Manuel Lousada Lopes: 0 Vintismo..., ob. cit., p. 84.

16 Íd., ibíd., p. 47.

17 VAZ, Maria João: Crime e sociedade. Portugal na segunda metade do século XIX, Oeiras, 1998.

18 SOUSA, Maria Leonor Machado de: «Narrativa de terror», en BUESCU, Helena Carvalhão (dir.): Dicionário do romantismo literário português, Lisboa, 1997, p. 352. V. referencias complementarias en SOUSA, Maria Leonor Maçhado de: "Introdução» a la edición de Paulo, o Montanhês, de
} 
Montanhês, de Arnaldo Gama (1853), ambientada en escenarios portugueses, aunque claramente entroncada con la estirpe de salteadores de Alejandro Dumas, considerados por el escritor portugués como «sublimes», por su "audacia y energía», su «sangre fría» y su «excéntrica generosidad» 19 .

Por otro lado, al calor de la guerra civil entre liberales y absolutistas (18321834), se produce un giro en la evolución de la figura del salteador como vulgar malhechor, precisamente en el momento en que los bandoleros aparecen implicados en acciones con contenido político, sensibilizados con el discurso de las elites antiliberales que habían salido derrotadas en la guerra. Estas conseguirían, en algunas regiones del norte de Portugal, atraer al bando contrarrevolucionario a líderes carismáticos de las cuadrillas de ladrones, poniendo de paso a su servicio la capacidad combativa e intimidatoria de sus hombres ${ }^{20}$.

Aunque esta situación es la que se registra hacia los años treinta, la recreación a la que nos referimos en este artículo, una tercera modalidad de estilización del bandido, es un fenómeno que se inicia con anterioridad - si bien no se sabe exactamente cuándo termina-, desencadenado por grupos dispersos de falsarios. Tenían por objetivo algo diferente de la publicación de una novela o del triunfo en un combate político bien definido, pero ello no obstó a que se sirvieran de ciertas técnicas de fabulación y aprovechasen a su favor la fama adquirida por los bandoleros de la época. Querían, sencillamente, extorsionar dinero, pero se debatían con limitaciones muy rigurosas, ya que estaban presos. Lejos de sus apetecidas víctimas, necesitaban un medio eficaz de aproximación. La epistolografía fue el arma de la que se pudieron servir.

\section{DOCUMENTACIÓN}

El fondo documental al que pertenecen las cartas de las que nos ocuparemos a continuación corresponde a procesos de naturaleza criminal juzgados en tribunal, prescritos y archivados («feitos findos»), relativos a la actuación de un tribunal de apelación portugués: la Casa da Suplicą̧ão. En el siglo XIX su jurisdicción no se limitaba exclusivamente a la corte de Lisboa (en casos de instrucción y de apelación), sino que también funcionaba como segunda instancia para todo el sur de Portugal y los archipiélagos de Madeira y Azores, además de acoger recursos como tribunal superior para apelaciones de los juzgados de

Arnaldo Gama [1853], Lisboa, 1981, pp. 9-30; FerreIRA, Maria de Fátima Sá e Melo: Rebeldes $e$ insubmissos. Resistências populares ao liberalismo (1834-1844), Lisboa, 2002, p. 252.

19 SoUSA, Maria Leonor Machado de: «Introdução», ob. cit., p. 17.

$20 \mathrm{Al}$ sur de Portugal (Alentejo y Algarbe) se registra un tipo de resistencia antiliberal diferente, ya que en esas regiones el pueblo hizo «su propia guerra» contra el nuevo régimen de forma relativamente ajena a las maniobras de propaganda política. Sobre el contraste regional en la actuación politizada de los salteadores portugueses entre 1834 y 1844, v. FERRREIRA, Maria de Fátima Sá e Melo: Rebeldes e insubmissos..., ob. cit., pp. 562-566.

Hispania, LXV/3, núm. 221 (2005) 991-1020 
segunda instancia - Tribunal da Relaşão- de Oporto (con jurisdicción sobre todo el centro y norte del reino) y de otros tribunales equivalentes de las colonias americanas y asiáticas ${ }^{21}$. Por lo tanto, se puede afirmar que la representatividad geográfica de los procesos recibidos para reapreciación en la Casa de la Suplicación es bastante amplia. En contrapartida, la representatividad cronológica es diminuta: el tribunal se extinguiría con la reforma administrativa llevada a cabo por Mouzinho da Silveira (1832-1833) y los autos anteriores al terremoto de Lisboa de 1755 habían desaparecido casi en su totalidad ${ }^{22}$. Así pues, la época sobre la cual este archivo conserva una documentación más numerosa va desde finales del siglo XVIII hasta 1834 . El conjunto de los procesos criminales archivados se sitúa en torno a los $30.000^{23}$.

Afortunadamente, los procesos criminales de la sección de Feitos Findos traen de vez en cuando unos anejos cosidos a sus folios. Son las pruebas que la policía entregaba al juez encargado de la instrucción del caso. De ese modo, muchas cartas privadas, aprehendidas en los registros o entregadas por los demandantes, han podido salvarse gracias a su conservación en los archivos, algo que se observa también en otros archivos judiciales, como los de la Inquisición portuguesa ${ }^{24}$. Tras el estudio de una parte considerable de los procesos clasificados como Feitos Findos — un cuarto del total, es decir, 7.850-, se estima que un $3 \%$ de ellos incluyen cartas privadas - a veces decenas de ellas-, lo cual supone que estamos manejando en este momento un corpus de 654 cartas, escritas entre 1792 y 1834 , anejadas a 218 procesos diferentes ${ }^{25}$.

Una clasificación provisional de estas cartas revela que la categoría temática más frecuente está integrada — como no podía ser de otra forma - por la correspondencia cuya redacción constituía por sí misma delito: «cartas de extorsión», sobre todo, pero también «cartas políticas». Le siguen, por orden de fre-

21 V. Hespanha, António Manuel: As Vésperas do Leviathan. Instituiz̧ōes e Poder Político. Portugal - Séc. XVII [1986], Lisboa, 1994, pp. 228-236; SuBTIL, José: «Os poderes do centro», en MATTOSo, José (dir.): História de Portugal, vol. 4, O Antigo Regime (1620-1807), coord. por António Manuel Hespanha, Lisboa, 1993, pp. 169-171; MARQUES, Mário Reis: «Estruturas jurídicas», en MATTOSO, José (dir.): História de Portugal, vol. 5, O Liberalismo (1807-1890), coord. por Luís Reis Torgal y João Lourenço Roque, Lisboa, 1993, p. 175.

22 V. Azevedo, Pedro de: Ano e meio de vida do arquivo dos Feitos Findos, separata de los Anais das bibliotecas e arquivos de Portugal, Coímbra, 1916, p. 10.

23 Debo esta información a la Dr. ${ }^{a}$ Teresa Saraiva, del Instituto Português dos Arquivos Nacionais/Torre do Tombo, responsable de la coordinación de los índices de los Feitos Findos. La tarea archivística en cuestión todavía no está terminada, razón por la cual no se tiene aún una noción exacta del número total de procesos.

24 V. MARQuilhas, Rita: A Faculdade das Letras. Leitura e escrita em Portugal no século XVII, Lisboa, 2000.

25 La muestra se inició de modo aleatorio, pero ese carácter se perdió a partir del momento en que se comenzó a tener en cuenta la relación entre los reos y sus respectivos procesos. En todo momento el objetivo fue localizar el mayor número posible de procesos judiciales con probabilidades de que contuviesen correspondencia privada. 
cuencia, las «cartas de relaciones privadas» (familia, amistad y amor) y, en el otro extremo, aparecen las escasas «cartas de negocios». Según su concentración cronológica, la categoría predominante es la de las cartas que constituían alguna variedad específica de extorsión, objeto del trabajo que nos ocupa: de las escritas por prisioneros que se hacían pasar por salteadores en libertad y listos para atacar han aparecido ya 85 cartas, clasificadas en su momento por la justicia como "cartas amenazantes» o, entonces, como "cartas aterradoras» ${ }^{26}$, redactadas entre 1822 y 1825 y parte integrante de 12 procesos diferentes ${ }^{27}$.

\section{IDENTIFICACIÓN DE LOS TEXTOS Y DE LOS AGENTES}

En el primer cuarto del siglo XIX llegó a Portugal el debate internacional sobre las reformas penales y sobre la conveniencia de aislar al recluso en un nuevo tipo de cárceles de celdas; no obstante, la cuestión se mantuvo en los círculos académicos hasta bastante tarde. El ordenamiento definitivo, que se inclinó más hacia el modelo de "Filadelfia corregido» que hacia el de "Auburn», solo sería aprobado en $1884^{28}$. En los años 20, la comunicabilidad en las prisiones del reino era, pues, una realidad raramente limitada. Es más, los domingos el ambiente podía llegar a ser de gran alegría, si damos crédito al humor hiperbólico de Camilo Castelo Branco cuando se refería a la cárcel da Relação de Oporto, antes de ser implantado el sistema de aislamiento en celdas: daba «gusto» estar preso, y parte de la diversión consistía en oír en primera persona el relato de las «proezas» de los delincuentes:

¿Qué buenos tiempos los de entonces! dicen los presos de ahora que vivieron aquellas francachelas domingueras. iEntonces sí que se podía estar preso por gusto! Yo tuve la suerte de aprovechar aquel hermoso paroxismo de la edad de oro. Los domingos se franqueaban las salidas de los calabozos y de las prisiones superiores. Salía todo el mundo al patio lleno de tenderetes de fruta, dulces y chuche-

26 Procesos en los que aparecen ambas clasificaciones: Ameaģadoras (amenazantes) - IAN/TT, Feitos Findos - Processos Crime, Letra J, Mazo 297, No22, Caja 761 [ $9^{\circ}$ cuaderno] fl. [2]r; Letra L, Mazo 8, No 8, Caja 19, fl. 38v; Letra M, Mazo 74, No 16, Caja 164, fl.[12]r; Letra J, Mazo 176, N$^{\circ}$ 127, Caja 469, fl.[1]r; Letra A, Mazo 17, No5, Caja 39, fl.19v; aterradoras - Letra M, Mazo 1, $\mathrm{N}^{\circ} 6$, Caja 2, fls. 13v, 21r.

27 Identificación de los doce procesos: Íd., Letra J, Mazo 113, $\mathrm{N}^{\circ}$ 9, Caja 308 (1821); Letra M, Mazo 44, No 6, Caja 89; Letra J, Mazo 113, No 9, Caja 308; Letra A, Mazo 24, No 3, Caja 52; Letra J, Mazo 92, $\mathrm{N}^{\circ} 3$, Caja 257; Letra J, Mazo 297, $\mathbf{N}^{\circ} 22$, Caja 761; Letra J, Mazo 304, $\mathbf{N}^{\circ} 38$, Caja 779; Letra L, Mazo 5, $\mathrm{N}^{\circ}$ 8, Caja 12; Letra M, Mazo 1, $\mathrm{N}^{\circ}$ 6, Caja 2; Letra P, Mazo 10, $\mathrm{N}^{\circ}$ 36, Caja 21; Letra C, Mazo 5, $N^{\circ} 1$, Caja 12; Letra L, Mazo 8, $\mathrm{N}^{\circ}$ 8, Caja 19; Letra J, Mazo 297, $\mathrm{N}^{\circ} 22$, Caja 761; Letra M, Mazo 74, $\mathrm{N}^{\circ} 16$, Caja 164.

28 V. BARREIROS, José António: «As instituições criminais em Portugal no século XIX: subsídios para a sua história», en Análise Social (Lisboa), 16-63 (1980-3. ${ }^{\circ}$ ), pp. 601-607, en particular la nota 36.

Hispania, LXV/3, núm. 221 (2005) 991-1020 
rías. Los amigos, compañeros de encrucijadas, se abrazaban y regocijaban, como en vísperas de un golpe propicio. Los asesinos contaban ufanamente las proezas que la justicia había sublimado a las alturas de la horca. Las mujeres de los condenados reían con ellos, como olvidadas de los grilletes 29 .

Cualquier hazaña «genial» protagonizada por los reclusos encontraba, pues, un contexto donde ser admirada y recreada, al igual que ocurriría con las «cartas aterradoras». Una de las primeras en ser escrita tuvo por autor moral a António José, o Maltezinho, un trabajador detenido en Lisboa y con pena de destierro en Angola por ser también un «notable salteador». El Maltezinho confesó que había mandado escribir a un destinatario importante, un diputado de las Cortes liberales, una carta firmada con el alias de João Espanba y enviada ficticiamente desde la ciudad de Évora. La carta, escrita con buena caligrafía, con papel, formato y pliegue muy convencionales, comenzaba y terminaba de forma respetuosa y cortés. El diputado era tratado por «Ilustrísimo Señor», y, entre otras fórmulas protocolarias, se expresaba el deseo de que disfrutase de «buena salud», en compañía de los suyos. Se despedía con la disculpa de que no quería «tomarle más tiempo» y firmaba como «su criado». Entre el encabezamiento y la despedida, «Su Señoría», la hermana, el administrador y algunos bienes - se hace referencia al ganado y al lagar - eran todos ellos objeto de las mayores amenazas si no le adelantasen treinta y tres monedas - que, afirma, serían devueltas más adelante- para socorrer a un bandido detenido. Para que el dinero fuese a parar a manos de la persona elegida, en el interior de la carta iba un papel recortado que serviría de contraseña. Al diputado, destinatario de la carta y la contraseña, se le hacía saber de paso, en una línea preñada de retórica y síntesis, que "podía estar tranquilo que nunca más habría de vivir tranquilo» si no accediese al pedido. Este es el texto integral de la carta:

\section{CARTA 1}

[Sobrescrito]: "Ao Sn. ${ }^{r}$ Viçente Antonio morador na Calçada do Duque n. ${ }^{\circ} 74$ »

Al Señor Viçente António vecino de la Calçada do Duque n. ${ }^{\circ} 74$

[Fecha]: «5 de março de 1822 "

5 de marzo de 1822

[Fórmula de encabezamiento]: «Ao Ilm. ${ }^{\circ}$ Sn. ${ }^{r}$ Viçente Ant. ${ }^{\circ}$ »

Al Ilustrísimo Señor Viçente Antonio

[Texto]: «Muito eide estimar que estas duas regras o vão achar disfrutando huma feliz»

Es mi mayor deseo que estas dos líneas lo encuentren disfrutando de buena

29 CASTElo BRANCO, Camilo: Memórias do cárcere, vol. 2 [1862], Lisboa, 1927, 7. a ed., pp. 62-63. 
«saude em comp. ${ }^{\text {a }}$ de tudo cuanto lhe pertença.» salud y en compañía de todo lo que le pertenezca.

«Sn. ${ }^{r}$ nós acupalmo a Vs. ${ }^{a}$ porque não pode ser por mennos » Señor, si nos dirigimos a Su Señoría es porque no puede ser de otra manera.

«agora damos a saber a Vs. ${ }^{2}$ que se haxa hum companheiro nosso prezo» Le hacemos saber a Su Señoría que un compañero nuestro se halla detenido

«na Çalla fixada da Cidade que se xama Antonio Roberto queremos» en la Sala Cerrada de la Ciudad, y que se llama Antonio Roberto. Queremos

«que Vs. ${ }^{\text {a }}$ me fassa o favor de 30 e tres moedas emprestadas até a feira» que Su Señoría me haga el favor de entregar 30 y tres monedas prestadas hasta la fiesta «de Maio e nisto se lhe dara o seu quero pois hé para livramento de nosso companheiro». de mayo, que entonces volverá a sus manos [...] pues es para librar a nuestro compañero

«e este dinheiro sera emtregue athe ao dia 11 sem falta alguma e adevirto que» y ese dinero será devuelto sin falta hasta el día 11 , y le aconsejo que

«hado xamar por este dito prezo em çegredo a grade e o dito Antonio Robreto» llame por dicho preso en secreto para que vaya hasta la reja y el dicho Antonio Roberto

«emtreguara uma cautella igual a esta e $\mathrm{Vm} .{ }^{\text {ce }}$ lhe emtreguara» le entregará una papeleta igual a ésta, y entonces Vuestra Merced le entregará

«logo logo o dito dinheiro e adevirto que seja emcartoxado e agora diguo que se» inmediatamente el dinero. Le aconsejo que lo meta en un paquete. Y también le digo que, si

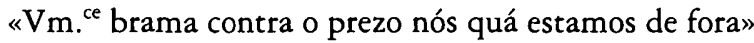

Vuestra Merced se atreviese a delatar con gritos al preso, nosotros estaremos fuera

«para o dispicar nos companeiro logo nos escreve daquillo que he passado e se» para vengarlo. Nuestro compañero nos va a escribir contando lo que haya pasado y, si

«nós temos por noteçia que hé aperzentado nas Cortes e em algum Tribunal Rial» tenemos noticia de que ha presentado queja en Cortes o en algún Tribunal Real,

«nós logo de tudo sabemos Snr. ${ }^{\circ}$ nos uzamos como homens de bem Vs. ${ }^{a}$ tem sido muito» nosotros sabremos de todo. Señor, nosotros nos comportamos como gente de bien. Su Señoría es muy

«respeitado e mal o seu feitor Antonio da Roza agora não queira perder» respetado, así como su administrador Antonio da Roza. Ahora bien, no quiera perder 
«muito por cuza pouca Snr. por nós sabemos de tudo cuanto çe passa e» mucho por tan poca cosa, Señor, pues nosotros sabemos de todo lo que ocurre y

«sabemos os passos que Vs. ${ }^{a}$ dá e mas da snr. ${ }^{a}$ soa manna e de tudo cuanto» sabemos los pasos que Su Señoría da, así como su señora hermana y de todo lo que

«lhe manda mas nós não queremos saber disto o que queremos hé que tão depreça receba»

manda hacer. Pero eso a nosotros no nos interesa. Lo que queremos es que, así que reciba

«esta mandará logo o que se lhe manda pedir e adevirto que se aqui ha» ésta, mande de inmediato lo que se le pide y le advierto que, si en esto hay

«falta os seus guados o paguarão porq. nós temos muito em que nos vingarmos pode» falta, sus ganados lo pagarán, porque nosotros tenemos mucho para vengarnos. Puede

"contar que lhe deitamos de rastos que athe o proprio laguar hade ser feito em» tomar por seguro que le echaremos todo abajo, hasta el mismo lagar ha de quedar en

«cinza e hade ser em tudo cuanto peguar lume por nós tambem tambem la temos amigos em»

cenizas y todo lo que pueda prender, pues nosotros también tenemos amigos ahí en

«Lisboa seguindo seus passos que Vs. ${ }^{a}$ dá e pode descançar que nunca mais» Lisboa siguiendo los pasos que Su Señoría da y puede estar tranquilo que nunca más

«hade viver descançado e pode contar se valler a este infeliz sera»

ha de vivir tranquilo, y puede contar que, si acude en socorro de este infeliz, será

«nosso padrinho e será respeitado e tudo cuanto lhe pertençe bem sabe» nuestro padrino y será respetado, así como todo lo que le pertenece. Bien sabe

«as desgraças que tem açeçodido em Lisboa far em campo que» de las desgracias que han sucedido en Lisboa, pues puede ser peor, que en el campo

«ahinda milhor se pode fazer e adevirto que cuando xamar por este prezo que pessa» todavía se puede hacer mejor. Y le advierto que cuando llame por este preso diga que

«que quer fallar com elle em segredo e que não vá a caza dos assentos porq.» quiere hablar con él en secreto, y que no vaya a la Casa dos Assentos, porque

«nós não que[...] queremos que seja a ondem nós lhe pedimos que hé» nosotros no [ilegible]. Queremos que sea donde nosotros se lo hemos pedido, que es

«as grades da mesma prizão q. hé a Salla fixada da Cidade.» junto a las rejas de la misma prisión, que es la Sala Fechada de la Ciudad.

Hispania, LXV/3, núm. 221 (2005) 991-1020 
[Fórmula de despedida]: «Com isto não emfado mais a Vs. ${ }^{a}$ deste seu criado»

Con esto no le tomo más tiempo a Su Señoría, de este su criado

[Firma]: «João Espenha campitão e mal os seus Companheiros»

João Espanha capitán junto con sus Compañeros

\section{[Lugar]: Evora ${ }^{30}$}

[Papeletas anejas, con la función de "contraseña»]: "Athé o 11 do mez de Março» Hasta el 11 del mes de marzo 31

Este tipo de asalto por carta, hecho en nombre del altruismo de los bandoleros, formó parte de una moda postal que, en la muestra que hemos aislado, se limitó a un único lugar, la prisión de la corte y ciudad de Lisboa, el Palacio Do Limoeiro. Las extorsiones, que no cesaron hasta 1825, se alargaron, pues, por un período de tres años, durante los cuales la policía fue reuniendo un conjunto no inferior a 85 cartas $^{32}$.

Una vez puestas a circular las primeras cartas, los detenidos tornaron más sofisticada su audacia, aprovechando la rica información almacenada en la memoria de individuos con trayectorias diversas que habían acabado por coincidir en la misma prisión. La Policía y la Justicia nos han dejado, precisamente, esa interpretación, al hacer referencia a que ese «nuevo e industrioso modo de robar» ${ }^{33}$ nacía de la comunicación entre los presos, y que parte de la solución consistía en aislar a los sospechosos:

Mande Su Señoría poner incomunicado a un preso cuyo nombre es Luiz Antonio de Leiros, que probablemente es el redactor de tales cartas, aprovechándose de las ideas que le transmiten los facinerosos que, desde las distintas tierras de este reino, vienen a la cárcel en que se encuentra [...]. (Carta de la Intendencia General de Policía, firmada por Simão da Silva Ferraz de Lima e Castro y dirigida al juez del barrio de Limoeiro. Lisboa, 10 de enero de 1824) 34 .

La observación del conjunto de los textos aprehendidos revela una primera clasificación: por un lado, las cartas escritas o dictadas aparentemente por ver-

30 Íd., Letra M, Mazo 44, N. ${ }^{\circ}$ 6, Caja 89, cuaderno 2, fls. 4r-5v.

31 Íd., ibíd., fl. 7r.

32 Por ahora, entre las cartas identificadas, la más tardía data del 1 de junio de 1825 y la más antigua del 17 de enero de 1822, pero hay que reseñar que manejamos en este momento una muestra que representa tan solo un cuarto del total de los procesos de los Feitos Findos-Crime. En los procesos ya vistos, relativos a años anteriores y posteriores a este trienio, han aparecido muchas cartas de extorsión, pero nunca en nombre de salteadores.

33 Decisión judicial del Tribunal de Apelación. Lisboa, 12 de agosto de 1824. IAN/TT, Feitos Findos - Processos Crime, Letra M, Mazo 1, N. ${ }^{\circ}$ 6, Caja 2, fl. 22r.

34 Íd. Ibíd., Anejo A, fl. [5].r

Hispania, LXV/3, núm. 221 (2005) 991-1020 
daderos salteadores detenidos temporalmente, que, al no poder hacerse al camino, inventaban estar en libertad y firmaban con seudónimo ${ }^{35}$; por otro, las cartas totalmente ficticias, escritas por individuos más inofensivos, los cuales, además de inventar también un seudónimo, se hacían pasar por bandoleros de carne y hueso, dispuestos para atacar si los destinatarios no los ayudasen a honrar una deuda de lealtad para con un «compañero» detenido.

En muchos casos, los destinatarios de las cartas tan sólo son mencionados, pero, cuando tenemos una información social junto al nombre, encontramos lo que sería previsible, o sea, las cartas van dirigidas a individuos adinerados, aunque exista alguna variedad en la categoría socio-profesional a la que pertenecían. Negociantes, industriales, aristócratas, cuadros superiores del ejército y de la administración, clérigos, labradores y señoras con bienes, son estas las categorías que se repiten. Se trata de un sector de población que, en el $40 \%$ de los casos, vivía en aldeas y pueblos del norte de Portugal; los demás se repartían entre Lisboa y su término (35\%) y los pueblos del Sur (25\%).

En cuanto al número de remitentes detenidos en el Palacio Do Limoeiro, si sumamos los dos confesos a los sospechosos presos, tenemos un puñado de individuos, no solo porque se dedicaban a practicar la extorsión en serie, sino también porque hubo casos archivados por falta de información. En lo concerniente a la identificación socio-profesional de los autores, se habla con alguna seguridad de un carpintero, de un barbero y de un maleante, los tres salteadores, así como de un individuo desempleado y un negociante. Los autores que confesaron su culpabilidad fueron tan solo dos (el trabajador-salteador Maltezinbo, que mandó escribir una carta, y un arrendatario, heredero del oficio de escribano, que confesó haber escrito varias cartas). En todo el intrincado proceso inherente a estas cartas-facilitar información sobre la potencial víctima, poner por escrito algunos dictados, enviar correspondencia o recibir el dinero fruto de la extorsión - parecen haber estado implicados por lo menos un sombrerero, dos vendedores ambulantes, un caballero de la Orden de Cristo que era oficial de policía, dos soldados, un número indeterminado de criadas, un cirujano, dos sirvientes en casas nobles y otro escribano. Aunque el contraste

35 Sentencia del Tribunal de Apelación, Lisboa, 17 de diciembre de 1822: «[...] re reconoció que el coautor Jerónimo es un desertor y el reo un completo maleante, y que ambos no tienen otro modo de vida que el hurto [...]. Además de este crimen, por el Anejo $\mathrm{n}^{\circ} 11$ se demuestra que, estando el reo en la cárcel Do Limoeiro, y no pudiendo repetir personalmente semejantes ataques para robar a los ciudadanos pacíficos, comenzaron a escribir desde la propia cárcel cartas amenazantes a diversas personas adineradas, exigiéndoles, en nombre de una cuadrilla de salteadores, abultadas sumas de dinero, y amenazándolas de muerte y otras fechorías en caso de que no le enviasen a la cárcel las sumas exigidas, remitiendo en dichas cartas ciertas señas y cifras en papel recortado que deberían ser conferidas con otras iguales que les debía presentar el preso que debía ser localizado en la cárcel, cuyo nombre coincidiría supuestamente con el indicado en cada una de las respectivas cartas denunciadas a la Policía, y que se hallan recogidas en los autos.», íd., Letra J, Mazo 113, N 9 Caja 308, fls. 11v-112v.

Hispania, LXV/3, núm. 221 (2005) 991-1020 
entre los dos grupos no sea tan drástico, también encontramos algo obvio: una relativa distancia social entre los más miserables -y también los mejor informados-, que extorsionaban, y los profesional o hereditariamente adinerados, los extorsionados. Esta oposición fue claramente puesta de relieve por policías y jueces, personajes que solían redactar comentarios sobre el crimen en la documentación de los procesos. De entre ellos, el que más información recopila es uno en el que están implicados nada menos que diez reos, y del que fueron archivadas 24 cartas de extorsión ${ }^{36}$. A pesar de la referencia al pavor generalizado de las "gentes» (i.), también aparece ocasionalmente alguna nota advirtiendo que los individuos que deberían recibir protección constituían una minoría (ii.), una minoría económicamente privilegiada (iii.):

i. Vistos estos autos [...] se demuestra que, habiendo aparecido en diferentes poblaciones de estos reinos repetidas cartas dirigidas a varias personas pidiéndoles dineros con expresiones amenazantes y causando gran susto y terror a las gentes la continuada repetición de las mismas cartas por ignorarse cuál sería su autor, que se presentaba como jefe de una numerosa cuadrilla de ladrones [...]. (Sentencia del Tribunal de Apelación, Lisboa, 2 de mayo de 1826) ${ }^{37}$.

ii. Remito a Su Excelencia las cartas anejas, que han llegado por correo a varias personas constantes en los sobrescritos de las mismas, las cuales están fugitivas de sus aldeas y refugiadas en esta villa a causa de las amenazas que en ellas se hacen. (Oficio dirigido a la Intendencia General de Policía por el juez de Arcos, José Maria de Sousa. Arcos de Valdevez, 21 de mayo de 1825) ${ }^{38}$.

iii. Me cumple [...] igualmente por esta ocasión loar a Vuestra Merced por el celo con que se ha empleado en este asunto y en el descubrimiento de los malhechores que de tal forma han infundido, con razón, tanto temor a los pacíficos y bonrados labradores $y$ propietarios. (Aviso enviado por el Intendente General de la Policía, barón de Rendufe, al juez de la villa de Chaves, António Bernardo de Figueiredo Abreu Castelo Branco. Lisboa, 15 de diciembre de 1824) ${ }^{39}$.

Para abreviar las referencias sobre la serie de acontecimientos generados por la circulación de este subgénero epistolográfico, referiremos tan solo que las instituciones de justicia y seguridad pública no ahorraron esfuerzos, aparentemente, para dar cumplida e ingeniosa respuesta al «industrioso modo de robar» urdido por los presos de Limoeiro. Los procesos dan fe, sobre todo a través de la correspondencia institucional, de las innumerables estratagemas detectivescas puestas en práctica para sorprender a los culpables en flagrante delito: haciendo pasar a un policía por cartero en la distribución de correspondencia o, en las entregas de pagos en mano, poner de portador a un policía o hacer acompañar al portador por guardias preparados para interceptar a quien apareciese para

36 Íd., Letra L, Mazo 8, N. ${ }^{\circ}$ 8, Caja 19 (1825).

37 Íd., ibíd., fl. 44 (cursiva mía, passim).

38 Íd., ibíd., apéndice A, fl. [7] r.

39 Íd., ibíd., cuaderno 2, fl. 23 r.

Hispania, LXV/3, núm. 221 (2005) 991-1020 
reclamar el dinero de la extorsión ${ }^{40}$. Los autores de las cartas contaban con esa posibilidad y, por ello, multiplicaban las amenazas para que sus destinatarios fuesen sigilosos, diciéndoles, por ejemplo:

[...] a ver si toma buena cuenta de lo que le digo. Quien venga, ique venga solo! Mire Su Señoría dónde se mete si falta o descubre el secreto. Acuda sin falta hasta el viernes que viene [...] Su seguro servidor, Manuel Vaz Bascavados, capitán de cuadrilla ${ }^{41}$.

Los resultados de las pesquisas variaban según los procesos. Hubo casos en que los implicados confesaron la autoría de las cartas y los cómplices fueron exculpados ${ }^{42}$; casos en los que el tribunal consideró sospechosos, o incluso culpables, a presos que defendieron su inocencia hasta el final ${ }^{43}$, y casos que comenzaron y acabaron en el más absoluto misterio ${ }^{44}$.

\section{ESTÁTICA Y DINÁMICA DE LAS CONVENCIONES VISUALES Y DISCURSIVAS}

Nos interesa en esta última parte poner de relieve algunos aspectos enunciativos y gráficos de las cartas «aterradoras», pues es precisamente en esos niveles - las propiedades intrínsecas de los enunciados y la presentación visual, respectivamente- donde ellas contribuyen a ensanchar nuestro conocimiento histórico sobre la forma como una sociedad de finales del Antiguo Régimen se representaba o, como dice Roger Chartier, «se tornaba menos opaca en la idea que se hacía de sí misma» ${ }^{45}$. En este caso, nos interesa la forma como esa sociedad representaba la escritura comunicativa que le era contemporánea.

En primer lugar se puede constatar que, en todas estas cartas, los enunciados son muy homogéneos, lo que confirma la idea insistentemente subrayada de que la epistolografía, como cualquier objeto que implique tecnología gráfica, muestra una clara tendencia a presentar características estables ${ }^{46}$. En ver-

40 Íd., ibíd., Anejo A, fl. [3]r; id., Letra J, Mazo 297, N 22, Caja 761, cuaderno 8, fl. \{9]r; íd., Letra M, Mazo 1, $N^{\circ}$ 6, Caja 2, fl. 21v; íd., Letra L, Mazo 5, $\mathrm{N}^{\circ}$ 8, Caja 12, Anejo 15, fls. [5]r-[6]v.

41 Íd., Letra J, Mazo 92, $\mathrm{N}^{\circ} 3$, Caja 257, fl.4v.

42 Íd., Letra M, Mazo 44, Nº, Caja 89; Letra L, Mazo 5, No 8, Ca-ixa 12; Letra M, Mazo 1, $\mathrm{N}^{\circ}$ 6, Caja 2.

43 Íd., Letra J, Mazo 113, No 9, Caja 308; Letra A, Mazo 24, No 3, Caja 52; Letra J, Mazo 92, $\mathrm{N}^{\circ}$ 3, Caja 257et; Letra J, Mazo 297, $\mathrm{N}^{\circ}$ 22, Caja 761; Letra M, Mazo 1, $\mathrm{N}^{\circ}$ 6, Caja 2; Letra $\mathrm{P}$, Mazo 10, $\mathrm{N}^{\circ}$ 36, Caja 21; Letra C, Mazo 5, $\mathrm{N}^{\circ} 1$, Caja 12; Letra L, Mazo 8, $\mathrm{N}^{\circ}$ 8, Caja 19; Letra M, Mazo 74, No 16 , Caja 164.

44 Íd., Letra J, Mazo 304, N 38, Caja 779; Letra M, Mazo 74, No 16, Caja 164.

45. CHARTIER, Roger: «Le monde comme représentation» en Annales E.S.C., 6 (nov.-dic.1989), p. 1514

46 V., por ejemplo, MARTIN, Henri-Jean: Pour une bistoire du liure (XVe-XVIIIe siècle). Cinq conférences, Nápoles, 1987, pp. 32-33 y PETRUCCI, Armando: Prima lezione di paleografia, Roma-Bari, 2002, p. 87. 
dad, la estabilidad no es una propiedad exclusiva del texto y de los objetos escritos, pues también se trata de una condición necesaria para que se puedan expresar con éxito intenciones a través de los enunciados orales. Como se viene defendiendo desde hace ya bastante tiempo en trabajos de filosofía del lenguaje, parece claro que la intención de la actuación a través de un enunciado, o sea, un «acto elocutivo», debe ser siempre convencional, mientras que no tiene por qué ocurrir lo mismo con la reacción del destinatario («acto perlocutivo») ${ }^{47}$. En la lengua escrita, y dado que su soporte es un objeto físicamente perdurable, se dan condiciones para que el rasgo de convencionalismo sea explotado hasta límites que lo efímero de los textos orales impide. Lo cierto es que, en cuanto despunta un nuevo género de texto escrito, de inmediato comienzan a surgir también los modelos para su normalización. Durante el siglo XIX, en sus cartas de salteadores inventados, los presos de Limoeiro se servían, de hecho, de modelos o plantillas para sus amenazas, en las que sólo se cambiaban la referencia a la cuantía exigida en la extorsión, el nombre y las circunstancias del destinatario y el lugar en que este residía ${ }^{48}$. La cortesía en el tratamiento era una pauta rigurosamente observada, como si formase parte de la propia materialidad de la carta. En cuanto al papel y al plegado, todo se mantenía muy invariable. Son escasas las cartas que no aparecen con el formato de media hoja plegada, escrita a partir del primer cuarto y utilizando la cara en blanco del último cuarto para, una vez plegada, colocar en ella el sobrescrito.

El encorsetamiento discursivo y material del que hemos venido hablando presentaba, paradójicamente, una maleabilidad notable en lo que toca a la construcción de la verosimilitud. La situación que se intentaba representar en las cartas era la de la existencia de una cuadrilla de salteadores verdaderamente temible y al acecho en las inmediaciones de la residencia del destinatario y, al mismo tiempo, la de dos contingencias innegables: i) se estaba ante la inminencia de un ataque violento; ii) el pago por parte del destinatario anularía esa posibilidad de violencia. En el mundo extra-discursivo, sin embargo, solo circulaban papeles que, en sí mismos, no tenían la fisonomía de ningún salteador, no robaban ni mataban, no se embolsaban dinero alguno. Contenían tan solo la suma de una serie de enunciados en los que se planteaba un compromiso de violencia, una aserción de la identidad bandolera y una orden de entrega de una cuantía de dinero. $\mathrm{Y}$, aun así, muchos destinatarios se asustaron y llegaron a pagar lo que se les pedía o, al menos, respondieron para intentar ganar así algún tiempo antes de la temida agresión (cf. Infra, Carta 4). O sea, el discurso

47 AUSTin, John L.: How to do Things with Words, Oxford, 1962, pp. 102-108.

48 IAN/TT, Feitos Findos - Processos Crime, Letra L, Mazo 8, No 8, Caja 19, fls.[10]r-[17]r; fls. [22]r-[25]r (primera plantilla); $2^{\circ}$ cuaderno numerado, fls.[3]r-[4] (segunda plantilla); $3^{\text {er }}$ cuaderno numerado, fls.3r-5v (tercera plantilla); ibíd., fls.37r-50v; e fls.53r-fls.62v (cuarta plantilla); íd., Letra L, Mazo 5, $\mathrm{N}^{\circ}$ 8, Caja 12, fls. [27-28]r e fls.[30-31]r; íd., Letra M, Mazo 1, $\mathrm{N}^{\circ}$ 6, Caja 2, Anejo A, fls. [6-7]v; [13-14]v; [17-18]v; [20-21]v (quinta plantilla); íd., ibíd., Anejo G, fls. [11$12] \mathrm{v} ;[13-14] \mathrm{v} ;[15-16] \mathrm{v} ;[17-18] \mathrm{v} ;[19-21] \mathrm{v} ;[22-23] \mathrm{v} ;[24-25] \mathrm{v}$ (sexta plantilla).

Hispania, LXV/3, núm. 221 (2005) 991-1020 
de la carta convencía. Y convencía apoyándose en un reducido número de fórmulas cuyo uso pretendía producir efectos compromisivos y constativos de violencia y bandidaje y, por consiguiente, directivos de $\mathrm{pago}^{49}$.

Veamos cómo eso se hizo posible. Para los aspectos compromisivos y constativos contribuían, por un lado, las proposiciones sanguinarias, moneda corriente en el discurso político de la época, caracterizado por un evidente terrorismo verbal entre las facciones liberal y miguelista $^{50}$, y que, por lo tanto, permitían que los destinatarios de las cartas identificasen sin esfuerzo el verdadero clima que se pretendía crear. La eventualidad del ataque podía ser referida de modos diferentes, a veces articuladas cuidadosamente, con particularidades contextuales según la víctima:

[...] En caso de que el señor abad no remita dicho dinero hasta el día 20 del corriente, puede contar como seguro que la primera vez que salte de su carruaje para ir a la asamblea a la que suele ir, a la hora de recogerse, que siempre es entre la una y las dos de la madrugada, le estarán esperando y será asesinado infaliblemente y también le meteremos fuego a las casas ${ }^{51}$,

0

[...] Yo soy el Cbuço, capitán de 2 cuadrillas de 96 hombres. Mire Su Excelencia que, si me falla o descubre el secreto, le meto fuego al palacio donde vive [...] junto con la quinta y las casas [...] y todo será arrasado. Mal se descuide Su Excelencia y se despertará cercado y rodeado por el fuegos2,

o incluso

[...] mire que lo rajamos en dos $53 /$ a la entrada de la casa será acuchillado y cortado en tiras y le meto fuego, arraso con cuanto Su Señoría tiene 54 / aunque

49 Utilizamos aquí la terminología de la pragmática lingüística en lo concerniente a la tipología de los actos elocutivos, tal como fue propuesta, tras el trabajo de Austin (cf. Supra), por John R. Searle: «Si adoptamos el objetivo de la elocución [es decir, la intención comunicativa] como una noción de base para clasificar los usos del lenguaje, entonces tenemos un número limitado de cosas básicas que podemos hacer con aquel: les decimos a los otros cómo son las cosas [Actos Constativos], intentamos que los otros hagan cosas [Actos Directivos], nos comprometemos a hacer cosas [Actos Compromisivos], expresamos sentimientos y actitudes [Actos Expresivos] e introducimos cambios con nuestro enunciado [Actos Declarativos]. A veces hacemos más de una de estas cosas en un mismo enunciado.», SEARLE, John R.: "A Taxonomy of Illocutionary Acts» [1971], en SEARLE, John L. (1985): Expression and Meaning. Studies in the Theory of Speech Acts, Cambridge, p. 29.

so V. LOUSADA, Maria Alexandre: «O Miguelismo...", ob. cit., p. 120, aunque la autora ha centrado su estudio en un período algo posterior al de estas cartas, 1828-1834.

51 IAN/TT, Feitos Findos - Processos Crime, Letra J, Mazo 297, No 22, Caja 761, fl.[6]r.

52 Íd., Letra L, Mazo 5, $\mathrm{N}^{\circ}$ 8, Caja 12, fl.[27]r.

53 Íd., Letra M, Mazo 1, $N^{\circ}$ 6, Caja 2, Anejo A, fls. [20-21].

54 Íd., ibid., Anejo G, fls. [13-14]. 
Vuestra Merced se esconda en el infierno, vamos allí a matarlo y a sacarle el corazón por la espalda5s.

Así y todo, era todavía necesario introducir algo de acción a este contenido propositivo, cuya credibilidad podría ser puesta en entredicho si no fuese acompañado de algo que lo acercase a los efectos que la entonación, la gesticulación y la remisión para un contexto físico compartido atribuyen a los enunciados orales. Para ello, los autores de las cartas «aterradoras» optaron por diferentes soluciones, aunque sin exceder los límites de una creatividad controlada. En 19 cartas se resolvió el problema comunicativo con un trabajo más pictográfico que alfabético: se dibujaron figuras consagradas en la tradición epistolográfica, como la «cruz» de las cartas misivas formales ${ }^{56}$, el "corazón» de las cartas de amor (Figura 1) y, sobre todo, las «armas» de las cartas de tocar ${ }^{57}$, pictogramas cuyo trazo podría servir para hacer visible todo lo que una cuadrilla de salteadores podría hacer (v. infra, Carta 2 y Figuras 2 y 3). Esta opción no era, con todo, la más usual. La más frecuente era la del trabajo sobre las fórmulas de despedida, cuando el autor estampaba su firma y repetía una identificación que probablemente ya había aparecido en el protocolo de la carta, después de las cortesías. Esa identificación podía, por ejemplo, corresponder a un apodo o alias semánticamente transparente por tratarse del nombre de un arma, como Chuço (el Chuzo), el nombre usado más veces, o Machadinho (el Hachita), o entonces el nombre de una raza de mala fama, o Cigano (el Gitano). A continuación podía aparecer algún complemento significativo que hiciera referencia a la cuadrilla, compuesta según los casos por $14,20,40,60,150 \ldots$ ladrones y algunas cualidades más:

capitán de la tiranía [...] con sus camaradas 1234567891011121314 capitán de 20 hombres a caballo capitán de una compañía de cuarenta camaradas

capitán de dicha compañía de [...] 60 camaradas bien entrenados y muy bien montados capitán de 150 ladrones montados, escapadores de los milagros

$5 s$ Íd., Letra M, Mazo 74, $\mathrm{N}^{\circ}$ 16, Caja 164, fl. [3]r-v.

56 Las cartas misivas aparecían tradicionalmente con una cruz al inicio, una figura que, al menos desde el siglo XVI, aparece aprobada en un texto legal como única ilustración que debería ocupar el encabezamiento de las cartas portuguesas: «Don Felipe, por la gracia de Dios, etc. Hago saber que en estilo de escribir unas personas a otras se guarde generalmente y sin excepción el orden siguiente: Comenzará la carta o papel por la razón o por el negocio por el que se escribe, sin poner debajo de la Cruz del inicio, ni al principio del renglón ningún título ni letra ni cifra que lo signifique [...]", albalá del 16 de septiembre de 1597, Ordeną̧ōes filipinas, lib. 5, Aditamentos [1870], Lisboa, 1985, pp. 1333-1334.

57 V. MARQUILHAS, Rita: «Orientación mágica del texto escrito»: Escribir y leer en el siglo de Cervantes comp. de Antonio Castillo, Barcelona, 1999, pp. 117-118. 
Además, la fecha colocada estaba próxima a la de la futura recepción, así como el lugar era cercano al de la dirección de la víctima. O sea, estaban bien identificadas en la estructura gráfica de la carta las secciones que más paralelismo guardaban con la presencia de los participantes y el contexto físico de una comunicación oral, y era precisamente ahí, en el protocolo y el escatocolo, donde se hacía mayor hincapié, para dotar de credibilidad al autor y de verosimilitud a su discurso.

En cuanto al aspecto directivo, los enunciados de las cartas eran prolijos a la hora de dar indicaciones sobre el modo como debería procederse al pago. Hay cartas que terminan con un recordatorio del ritual para el pago de la extorsión expuesto ya anteriormente al inicio de las mismas ${ }^{58}$. Como complemento de esos mismos enunciados, podían ser incluidos también dibujos o algunos materiales. En varias cartas se aprovechaba el espacio interior para introducir pedazos de papel con formatos o dibujos diferentes que servirían de contraseña para el momento de la entrega del dinero. Una vez más, encontramos aquí el aprovechamiento de figuras convencionales como el corazón y las armas (Figura 4).

Antes de concluir, habría que reseñar que tan sólo hemos traído a colación algunas representaciones de las «cartas aterradoras», por tratarse de aquellas que, en nuestra opinión, presentan un mayor interés para la historia de la cultura escrita del Antiguo Régimen. Ha quedado de fuera, por ejemplo, la representación de las cualidades morales y sociales del sujeto de la enunciación, un proceso que suponía un esfuerzo considerable por parte de los autores de esta experiencia comunicativa, que así intentaban nivelarse según los patrones supuestos en sus distinguidos destinatarios y, de ese modo, candidatarse a legítimos interlocutores de los mismos ${ }^{59}$. Ese parece haber sido un modo adicional de contribuir a la aceptabilidad de aquellos enunciados, pero tanto éste como los otros rasgos convergen en una característica constante de las «cartas aterradoras»: eran variaciones sobre una cortesía que no se pretendía poner en tela de juicio, sino capitalizarla en beneficio de una extorsión exitosa.

ANEJO

Se incluyen en este Anejo otras tres cartas ilustrativas del corpus «aterrador». La Carta 2 pone de manifiesto el recurso a la alianza entre texto ideográfico y texto alfabético. La Carta 3 presenta un modelo de insistencia cuando la primera tentativa de extorsión no prosperaba. En la Carta 4 se recoge la respuesta de una potencial víctima.

58 Íd., Letra M, Mazo 1, No 6, Caja 2, Anejo A, fls. [19-20] e fls. [24-25]; Letra L, Mazo 5 , $\mathrm{N}^{\circ}$ 8, Caja 12, fls. [30-31].

59 Cf. Supra Carta 1: «Señor, nosotros nos comportamos como gente de bien», o «[...] he hablado por letra con muchos hidalgos y todos me han correspondido"; IAN/TT, Feitos Findos Processos Crime, Letra J, Mazo 297, No 22, Caja 761, fl. [22]r-v.

Hispania, LXV/3, núm. 221 (2005) 991-1020 


\section{CARTA 2}

[Sobrescrito]: "Ao Snr. ${ }^{\circ}$ P. ${ }^{e}$ Diogo D. ${ }^{s} \mathrm{G} .{ }^{\mathrm{e}} \mathrm{m} .{ }^{\text {os }}$ asistente em Villa Verde de Araia» Al Señor Padre Diogo. Dios lo guarde muchos años, asistente en Vila Verde da Raia

[Fecha]: «3 de nobr. ${ }^{\circ}$ de $1824 »$

3 de noviembre de 1824

[Fórmula de encabezamiento]: «Snr. P. Diogo»

Señor Padre Diogo

[Lugar]: Chaves

[Texto]: «Eu estimo q. Vm. ${ }^{\text {ce }}$ tenha saude em comp. ${ }^{a}$ do»

Mucho estimo que Vuestra Merced se encuentre con salud en compañía de

"çeu dezejo pois eu fico pronto e mais os meus camaradas p. ${ }^{\text {a }}$ tudo q."

quien más desee, pues yo estoy a sus pies, y también mis camaradas, para todo lo que

"Vs. ${ }^{a}$ detreminar "

Su Señoría tenga por bien determinar.

«Snr. ${ }^{\circ} »$

Señor

«Eu lhe parteçipo a Vm. ${ }^{\text {ce }}$ q. cheguei as alturas de Chaves aonde»

Le hago saber a Vuestra Merced que he llegado a estas tierras de Chaves, en las que he

"reçebi huma carta de hum primo meu chamado Franc. Joze Coelho Carapuça aonde» recibido una carta de un primo mío llamado Francisco Joze Coelho Carapuça, en la que

«me dis q. se acha prezo na Cad. ${ }^{a}$ nova da Corte em Lisboa»

me dice que se encuentra detenido en la Cárcel Nueva de la Corte, en Lisboa, desde

"aonde me manda pedir 60 moedas p. ${ }^{\text {a } ~ o ~ s e u ~ l i v r a m t . ~} .^{\circ}$ aonde eu não poço de deixar de» donde me manda pedir sesenta monedas para su fianza, a lo cual yo no puedo excusarme a

"comresponder mas me faz perzizo ocopar alguns snres. p. ${ }^{\text {a }}$ este fim asim quero q. » corresponder, pero necesito ocupar a algunos señores para ese fin. Así pues, quiero que

"Vm. ${ }^{c e}$ me faça o favor de me emprestar vinte moedas he $\mathrm{Vm} .{ }^{\mathrm{ce}}$ "

Vuestra Merced me haga el favor de prestarme veinte monedas y Vuestra Merced

«remetera este dinr. ${ }^{\circ}$ o meu primo sera emtregue pello seguro he $\mathrm{p}^{\mathrm{a}}$ ceu governo de» remitirá ese dinero a mi primo. Será entregado de forma segura. Para el gobierno de

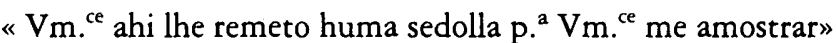

Vuestra Merced aquí le envío una cédula, para que Vuestra Merced me la muestre

Hispania, LXV/3, núm. 221 (2005) 991-1020 
"condo eu lhe for a pagar este dinr. ${ }^{\circ} \mathrm{q}$. eu lhe heide pagar $\mathrm{p}^{\mathrm{a}}$ o Reis he»

cuando yo vaya a pagarle este dinero, que se lo pagaré por la altura de Reyes..Y,

"comrespondendo Vm. ${ }^{\text {ce }}$ na forma decalarada sempre cera respeitado e tudo conto for" cumpliendo Vuestra Merced de la forma declarada, siempre será respetado, así como

«de Vm. ${ }^{\text {ce }}$ e sera recomendado pello meus camaradas»

todo lo suyo, y será recomendado por mis camaradas para que actúen del mismo modo.

«este o dinr. ${ }^{\circ}$ ade estar emtregue athe o dia 26 de nobr. ${ }^{\circ}$ a este meu primo he» Este dinero deberá ser entregado hasta el día 26 de noviembre a este primo mío y, en

«não comrespondendo the irei abrazar tudo conto for de $\mathrm{Vm} .{ }^{\text {ce }}$ sera paçado tudo a» caso de que no cumpla, iré a abrasar todo cuando pertenezca a Vuestra Merced. Todo

«fogo tudo conto estiver em caza e Vm. ${ }^{\text {ce }}$ ficara feito im coartos» será pasado a fuego, todo lo que tenga en casa, y Vuestra Merced quedará descuartizado

«he ceu povo ficara derotado asim não queira q. se lhe faça» y los suyos derrotados. Por todo lo expuesto, no quiera Vuestra Merced que se le hagan

«estes emçultos q. eu lhe juro por estas cruzes [Figura 2] se me faltar comforme vai» tales injurias, que yo le juro por estas cruces [Figura 2] que, si me falla, conforme va

«este coração lhe heide fazer o seu [Figura 3] he tudo conto estiver em sua caza ״ este corazón, así le haré yo al suyo [Figura 3] y a todo lo que esté en su casa.

«isto he não sendo imtregue o meu primo da d. ${ }^{a}$ contia q. eu lhe mando pedir a Vm. ${ }^{\text {ce }}$ » Y así si no le entrega a mi primo la cuantía que le vengo a pedir ahora a Vuestra Merced.

«q. eu tão bem lhe escrevo p. ${ }^{a}$ saber de qm. ade reçeber o dinr. ${ }^{\circ}$ asim logo» Que yo también le escribo para saber de quién ha de recibir el dinero. Así pues, luego

"q. Vm. ${ }^{\text {ce }}$ areceba esta mandara resposta o meu primo na Cad. ${ }^{a}$ nova» que Vuestra Merced reciba esta mandará respuesta a mi primo, a la Cárcel Nueva de la

"da Corte im Lisboa chamado Franc. ${ }^{\circ}$ Joze Coelho Carapuça p. ${ }^{a}$ elle me parteçipar de» Corte en Lisboa, llamado Francisco Joze Coelho Carapuça, para que él me participe de

«a comrespondença q. Vm. ${ }^{\text {ce }}$ tem $\mathrm{p}^{\mathrm{a}}$ eu detreminar o q. heide fazer com isto» la correspondencia de Vuestra Merced y yo determine lo que tenga que hacer.

[Fórmula de despedida]: «ad. ${ }^{\text {s }}$ the vista deste seu cr. ${ }^{\circ}$ » adiós, hasta la vista, de éste su criado 
[Firma]: «Ant. ${ }^{\circ}$ Joze Chuço capitão de corenta camaradas» Antonio Joze Chuço, capitán de cuarenta camaradas 60

\section{CARTA 3}

[Sobrescrito]: «A Exm. ${ }^{\text {a }}$ Snr. ${ }^{\text {a }}$ Condeça de Nouzia» A la Excelentísima Señora Condesa de Nouzia

[Lugar]: «Lx. ${ }^{2} »$

Lisboa

[Texto]: «Ha dias remeti a VEx. ${ }^{a}$ hua carta do Limoeiro fazendo ver a VEx. ${ }^{2}$ » Hace días remití a Su Excelencia una carta desde Limoeiro, haciéndole ver Su

«q. eu hera o xuço o Chuço capitão de huma coadrilha de ladroes a pedir a VEx. ${ }^{a}$ » Excelencia que yo era el Chuzo, capitán de una cuadrilla de ladrones, pidiéndole a Su

«20 moedas prestadas p. $^{\text {a }}$ salvar 1 camarada meo q. esta neça terra prezo»

Excelencia 20 monedas prestadas para salvar a 1 camarada mío que está preso en esa

«no Limoeiro portanto VEx. ${ }^{a}$ tem faltado eu purtesto que se VEx. ${ }^{a}$ "

tierra, en Limoeiro. Y sin embargo Su Señoría ha fallado. Le aseguro que si Su Señoría

«me faltar que pasara por grandes prigos tudo qt. ${ }^{\circ}$ VEx. ${ }^{a}$ tem lhe»

me vuelve a fallar pasará por grandes peligros. Todo cuanto Su Excelencia tenga se lo

«arazo e lhe mando lançar fogo segredo maes segredo tudo tem respt. ${ }^{a}$ logo q.»

arraso y le mando meter fuego. Secreto más secreto. Todo tiene respuesta. Así que Su

"VEx. ${ }^{\text {a }}$ reçeba esta mandara a Cadeia da Cidade o dinheiro en papel»

Excelencia reciba la presente, mandará a la cárcel de la ciudad el dinero, en papel

"fixado em carta com o sobre escrito o Joaq. ${ }^{\mathrm{m}} \mathrm{d}$ Mata Castro e q. ${ }^{\mathrm{m}}$ for"

cerrado en carta, indicando en el sobrescrito A Joaquim da Mata Castro, y quien vaya

«não va de dia va as 7 horas da note e q. ${ }^{\mathrm{m}}$ for que q. ${ }^{\mathrm{m}}$ for q. se ponha nas»

que no vaya de día, que vaya a las 7 de la tarde, y que quien vaya que se ponga en las

«escadas do Limoeiro o pe das pedras do entulho em ovindo xamar pelo nome do" escaleras de Limoeiro, junto a los escombros y que, en oyendo llamar por el nombre de

«Fernandes que va a grade onde estiver o prezo q. entregue o q. levar com tanto»

Fernandes, que vaya a la reja donde esté el preso y le entregue lo que lleve de tal forma

60 Íd., Letra L, Mazo 8, No 8, Caja 19, cuaderno 2, fl. [3].

Hispania, LXV/3, núm. 221 (2005) 991-1020 
«q. não saiba do negoçio veja VEx. ${ }^{a}$ no que se mete e o que for» que no se sepa del negocio. Mire Su Excelencia dónde se mete y, con lo que sea,

«o depois não se queixe q. morre nas m. ${ }^{\text {as }}$ maos segredo olhe que»

después no se queje si muere a manos de éste_que le escribe. Y guarde el secreto, porque

"padeçe se o descobre veja o que faz se me falta eu conto com VEx. ${ }^{\text {" }}$ "

padecerá si lo descubre. Ojo con lo que hace si me falla. Cuento con Su Excelencia y

«e purtesto de pagar a VEx. ${ }^{{ }^{a}}$ »

me comprometo a pagarle.

[Fórmula de despedida]: «Sou V. ${ }^{\text {or }} \mathrm{C} . »$

Su seguro servidor

[Lugar y fecha]: «Pegois 14»

Pegões 14

[Firma]: «J. ${ }^{e}$ Ant. ${ }^{\circ}$ Xuço»

José António Xuço61

\section{CARTA 4}

[Sobrescrito]: «Sr. José Rodrigues Laborda na rua da Deza ${ }^{0} 31$ em casa da Sr. ${ }^{a}$ Victoria Lisboa»

Señor José Rodrigues Laborda, en la Rua da Adiça, nº 31, en casa de la Señora Vitória, Lisboa

[Fórmula de encabezamiento]: «Sr. Ant. ${ }^{\circ}$ Chuço»

Señor Antonio Chuço

\section{[Lugar]: Tondela}

[Texto]: «Eu cá recebi huma carta sua datada em tres de Septembro passado, na qual He recibido aquí una carta suya fechada a tres de septiembre pasado en la cual

«Vmce. me pede, lhe remetta sincoenta mil reis em papel, e agora recebo outra, em Vuestra Merced me pide le remita cincuenta mil reales en papel, y ahora recibo otra en

«q. Vmce. me argue da falta de resposta e pede, lhe mande trinta que Vuestra Merced me arguye con la falta de respuesta y pide le mande treinta

«moedas em papel, porém vou a dizer a Vm. ${ }^{\text {ce }} \mathrm{q}$. qd. ${ }^{\circ}$ recebi a primeira, monedas en papel. Pues bien, le diré a Vuestra Merced que cuando recibí la primera,

61 Íd., Letra L, Mazo 5, No 8, Caja 12, fls. [24]r-[25]v. 
«apesar de ter pagamentos a fazer na feira de Viseu, e querer remir algumas a pesar de tener algunos pagos por hacer en la feria de Visẹu y querer redimirme de algunas

«vexações, em q. me vi nessa occasião, sempre lhe remetteria, qd. ${ }^{\circ}$ não fosse toda a conta, vejaciones en que me vi en esa ocasión, tenía pensado remitirle, si no toda la cuenta,

«ao menos p. ${ }^{\text {te }}$ della; porém desconfiei, não fosse a sua carta de hum meu parente que se al menos parte de ella; con todo, desconfié, no fuese su carta de un pariente mío que se

«q. se acha à muitos tempos nessa Cid. e, e he meu inimigo declarado e lembreime, q. era halla hace ya un buen tiempo en esa ciudad, y es mi enemigo declarado y pensé que era

«gamboina delle p. ${ }^{a}$ me vexar, e mt. ${ }^{\circ}$ mais desconfiei, p. ${ }^{\mathrm{r}}$ se me assemelhar a letra una trampa suya para burlarse de mí, y desconfié aún más por ser muy semejante la letra

«com a delle: este foi o motivo, p.q. não respondi logo, agora vejo a segunda a la de él. Este fue el motivo por el que no respondí al punto. Ahora veo la segunda

«carta, em q. Vm. ${ }^{\text {ce }}$ me pede trinta moedas, e sou a dizer a $\mathrm{Vm} .{ }^{\text {ce }}$

carta en que Vuestra Merced me pide treinta monedas y voy a decirle a Vuestra Merced

«q., supposto tenho bens de raiz, não tenho dinheiros, nem tem vindo emporte de alguns

que, aunque tengo bienes de raíz, no tengo dineros ni me han reembolsado de algunos

«vinhos, q. remetti p. a America, e apenas hum pequena porção, q. há tempos me veio,

vinos que envié a América y tan solo una pequeña porción que hace tièmpo me vino,

«logo paguei no Porto huma huma divida q. ahi tinha, e p. ${ }^{\circledR}$ cujo o credor já estava con ella pagué en Oporto una deuda que allí tenía, y por cuyo acreedor estaba ya

«ameaçado com execução: eu vivo a credito, e p. ${ }^{\mathrm{r}}$ pagamento de outras dividas, deixarei de

amenazado con ejecución. Yo vivo a crédito y para pagar otras deudas dejaré que

«executar alguns bens pelos meus credores, como he hum q. agora me

algunos acreedores me tomen algunos bienes, como es el caso de uno que ahora me

«obriga p. ' cento e tantas moedas, o q. me tem afligido bem, no entanto eu obliga a ciento y pico monedas, lo que me tiene bastante preocupado. De todas formas, yo

«p. ${ }^{\text {r o seg. }}{ }^{\text {te }}$ correio remetterei a Vm. ${ }^{\text {ce }}$ dez moedas e irei continuando com as por el siguiente correo le remitiré a Vuestra Merced diez monedas y continuaré con las 
«remesas, q. poder, e p. ${ }^{\mathrm{r}}$ esta primeira remesa heide fazer toda a diligencia, remesas que pueda. Y para esta primera remesa haré todas las diligencias que pueda,

«ainda q. cuide de empenhar toda a m. ${ }^{\mathrm{a}}$ casa, e tambem não he bom ir junto p. ${ }^{\mathrm{r}}$ algum aunque tenga que empeñar toda mi casa. Pero tampoco es bueno que en este asunto uno

«descaminho q. pode haver, e mm. ${ }^{\circ}$ pelo volume,

se equivoque de camino, y menos aún teniendo en cuenta la suma de que se trata. Por

«e sempre queria, q. Vm. ${ }^{\text {ce }}$ me fizesse certo, q. a letra era sua p. ${ }^{\mathrm{r}}$ me tirar de dúvidas, eso le pido encarecidamente a Vuestra Merced que me confirme y me saque de dudas

«o q. podia fazer p. ${ }^{\mathrm{r}}$ algum seu amigo, q. me

sobre que la letra es suya, lo cual podía hacer mandando a algún amigo suyo que me

«conheça, e q. me certifique da sua, no q. tambem quero todo o segredo,

conozca y que me certifique que es suya, para lo cual también quiero el mayor secreto.

«no entanto não enfado mais a $\mathrm{Vm} .{ }^{\mathrm{ce}}$ a $\mathrm{q}^{\mathrm{m}}{ }^{\mathrm{m}}$ desejo saude perfeita, e felicidades.

Así pues, no le tomo más tiempo a Vuestra Merced, a quien deseo salud y felicidad.

[Fórmula de despedida]: «De Vm. ${ }^{\text {ce }}$ attento e cr. ${ }^{\circ}$ "

De Vuestra Merced atento y servidor

[Lugar y fecha]: «Tondella 21 de 8 br. ${ }^{\circ}$ de 1823 »

Tondela, 21 de octubre de 1823

[Firma]: «Jollião Nunes de Sa»62

62 Íd., Letra J, Mazo 297, No 22, Caja 761, fls. [34]r-[34]v. 
FIGURA 1

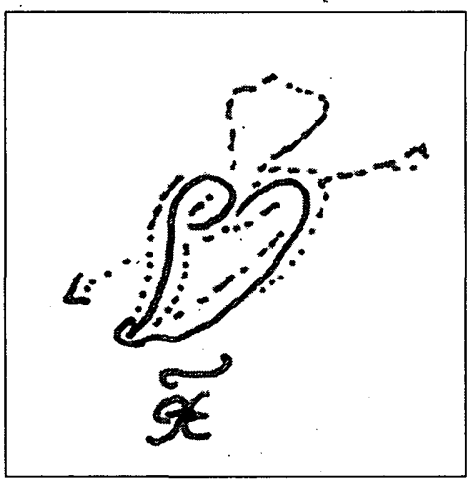

«... Destte meu coração

q. espera alivio da tua mão eu fico nesta afelição»

[«...De este mi corazón / que espera alivio de tu mano / yago en esta aflicción»]

Carta de amor atribuida a Francisco Xavier Vieira, criado, de 17 años de edad, morador en Lisboa. Lisboa, [1819], IAN/TT, Feitos Findos - Processos Crime, Letra F, Mazo 11, N 25 , Caja $26,6^{\circ}$ cuaderno, fl. [15]v.

FIGURA 2

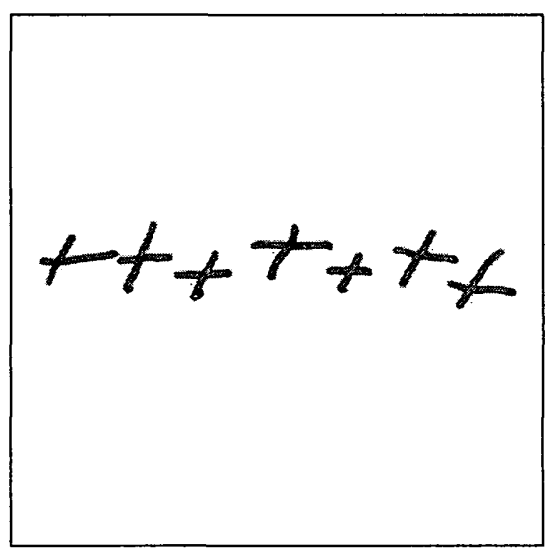

«... eu lhe juro por estas cruzes...»

[«...yo le juro por estas cruces...»]

Carta de extorsión enviada al Padre Diogo, vecino de Vila Verde da Raia, escrita en nombre de António José Chuço, salteador. Lisboa, 3 de noviembre de 1824 (v. Carta 2), IAN/TT, Feitos Findos - Processos Crime, Letra L, Mazo 8, No 8, Caja 19, Anejo 1, fl. 4v.

Hispania, LXV/3, núm. 221 (2005) 991-1020 


\section{FIGURA 3}

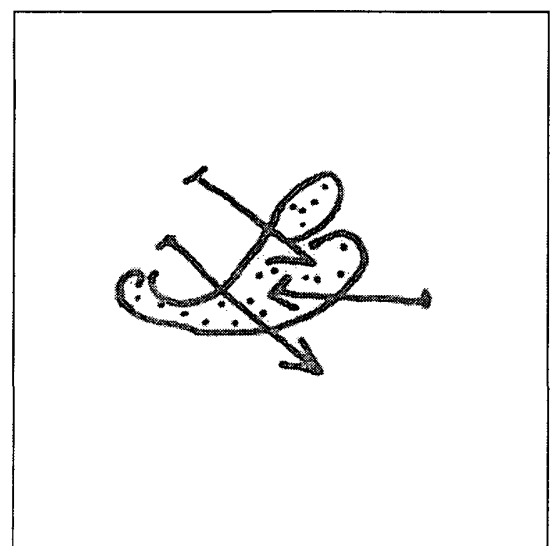

«... se me faltar comforme vai este coração lhe heide fazer o seu...»

[«... si me falla, conforme va este corazón, así le haré yo al suyo...»]

Carta de extorsión enviada al Padre Diogo, vecino de Vila Verde da Raia, escrita en nombre de António José Chuço, salteador. Lisboa, 3 de noviembre de 1824 (v. Carta 2), IAN/TT, Feitos Findos - Processos Crime, Letra L, Mazo 8, No 8, Caja 19, Anejo 1, fl. 4v.

\section{FIGURA 4}

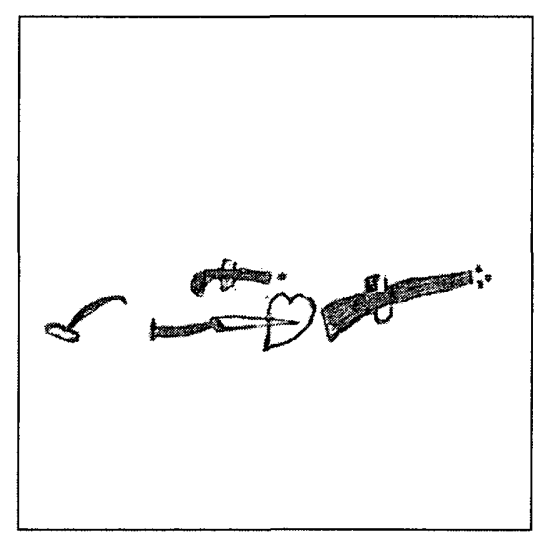

«Eu Capp. ${ }^{\text {om }}$ Joze Maria Sigano mando pase seguro porq. emprestou moedas 10 p. $^{2}$ noço camarada prezo o Sr. M..$^{\text {el }}$ Telles em dia 27»

[Yo, capitán Joze Maria Sigano mando este pase seguro, porque prestó 10 monedas para nuestro camarada preso, al Sr. Manuel Teles, el día 27»]

Contraseña incluida en una carta de extorsión enviada a Manuel Teles, labrador, vecino de la villa de Fronteira, escrita en nombre de José Maria Cigano, salteador. Lisboa, [1824], IAN/TT, Feitos Findos - Processos Crime, Letra C, Mazo 5, No 1, Caja 12, $6^{\circ}$ cuaderno, fl. Gr. 